acid (DNA), forming adducts which are detectable by immunological techniques, so individuals, at high risk from certain carcinogens, might possibly be screened using polyclonal or monoclonal antibodies to measure carcinogen:DNA adduct levels. Furthermore, this method might be employed not only to monitor the genotoxic effect but also to assess the efficiency of DNA repair. ${ }^{1+21}$ Nevertheless, we need to remember that if a neoplasm is not amenable to treatment (for example, mesothelioma from asbestos exposure) there is little point in regularly drawing a patient's attention to the sword of Damocles.

When early diagnosis can lead to successful treatment, however, we need to decide who should be put under surveillance-and this decision must be arbitrary. We cannot hope to trace everyone who might have been exposed throughout the long latent period of development of an occupational cancer, perhaps a lifetime. Factors that need to be considered include the length and severity of exposure to the carcinogen and possibly the lifestyle of genetically determined metabolic state of the individuals at risk. The decision requires good science, sound judgment, and common sense. The long latent period causes almost insurmountable obstacles to organisation in large as well as small enterprises. Not many workers nowadays remain with the same employer for up to 40 years. So how is long term surveillance to be organised? To bring the problem home-What personal exposure records has the National Health Service kept of nurses and pharmacists handling cytotoxic drugs? Should they be subjected to a lifetime of medical surveillance, simply on the basis of perceived risk from mutagenicity, though no increased incidence of cancer has been reported? ${ }^{22}$ So far we have found no universal answer to these problems.

The Health and Safety Commission is concerned with prevention (including the identification and assessment of hazards) and has called for certain records of exposure to be kept for up to 50 years, but it does not appear to have considered whether some exposed workers should be identified for follow up or how this might be achieved. ${ }^{23}$ In the rubber industry a successful programme has been operated by the British Rubber Manufacturers' Association which began by an approach to men working in the industry. They were, of course, aware of the problems and perhaps some of their friends and colleagues had developed tumours. When the Health and Safety Executive attempted to extend the scheme to men who had left the industry many years previously and who had to be traced through national registers the response rate was considerably lower $(H \mathrm{G}$ Parkes, personal communication), which illustrates the separation which still exists between occupational and other medical services.

We need to develop in this area, possibly using the family doctor (or more likely over a 40 year period a succession of family doctors). Theoretically, the use of central (NHS and National Insurance) registers would help, but the response by former workers may be uncertain - and apart from apathy not everyone wants a yearly reminder of a possibly remote risk to his life. Sir Herman Bondi has perceptively reminded us that the death rate in any community is one per person. ${ }^{24}$ How far is it morally justifiable, how far is it economically justifiable, continually to pursue people late into old age with the object of making a presymptomatic diagnosis? Should we look at such questions, or is it better to continue to ignore them?

For the present a general practitioner, aware of his patient's present and past occupations, must be alert for early evidence of an occupational cancer. Many hospital clinicians, aware of the connection between the cancers with which they deal and occupation, frequently do inquire into the occupational history. But by that time the establishment of the occupational link generally serves to point the patient only towards some form of financial benefit-important and useful, but no substitute for primary and secondary prevention.

Professor of Occupational Health,
University of Manchester,

W R LEE

University of Manchester,

\section{Mancher Mis}

1 Baxter PJ, McDowall ME. Occupation and cancer in London: an investigation into nasal and bladder cancer using the Cancer Atlas. Br F Ind Med 1986:43:44-9.

2 Harnden DG. Views on the aetiology of some cancers. I R Coll Physicians Lond 1980;14:106-10. Doll R, Peto R. The causes of cancer: quantitative estimates of avoidable risks of cancer in the United States today. FNCI 1981;66: 1194-308.

4 Ro FJC. Avoidable cancer risks with special reference to occupational factors. Br Med $\mathrm{J}$ 1981;283:1421-2

5 Alderson M. Industrial cancer-whose responsibility? Ann Occup Hyg 1978;21:285-91.

6 Calkins DR, Dixon RL, Gerber CR, Zarin D, Omenn GS. Identification, characterization, and control of potential human carcinogens: a framework for federal decision making. $7 N C I$ 1980;64:169-76

Lower GM. Arvlamines and bladder cancer causality: application of conceptual and operational criteria. Clin Pharmacol Ther 1983;34:129-35.

Selikoff IJ, Hammond EC, Churg J. Asbestos exposure, smoking, and neoplasia. FAMA 1968:204:104-10.

9 Omenn GS. Advances in genetics and immunology: the importance of basic research to prevention of occupational diseases. Arch Enoiron Health 1984;39:173-82.

10 Emery AEH, Anand R, Danford N, Duncan W, Paton L. Aryl-hydrocarbon-hydroxylase inducibility in patients with cancer. Lancet 1978; : $470-2$.

11 Trell E, Korsgaard R, Hood B, Kitzing P, Norden G, Simonsson BG. Aryl hydrocarbon hydroxylase inducibility and laryngeal carcinomas. Lancet 1976;ii: 140.

12 Cartwright RA, Glashan RW, Rogers HJ, et al. Role of N-acetyltransferase phenotypes in bladder carcinogenesis: a pharmacogenetic epidemiological approach to bladder cancer. Lancet 1982;i:842-6.

13 Evans DAP, Eze LC, Whibley EJ. The association of the slow acetylator phenotype with bladde cancer. F Med Genet 1983;20:330-3.

14 Perera FP, Weinstein IB. Molecular epidemiology and carcinogen-DNA adduct detection: new approaches to studies of human cancer causation. $\mathcal{F}$ Chronic Dis 1982:35:581-600.

15 Arnott MS, Yamauchi T, Johnston DA. Aryl hydrocarbon hydroxylase in normal and cancer populations. In: Griffin AC, Shaw CR, eds. Carcinogens: identification and mechanisms of action. New York: Raven Press, 1979:145-56.

16 Fox AJ, White CG. Bladder cancer in rubber workers. Lancet 1976; ; 1009-11.

17 Cartwright RA, Gadian T, Garland JB, Bernard SM. The influence of malignant cell cytology screening on the survival of industrial bladder cancer cases. I Epidemiol Community Health 1981:35:35-8.

18 Kumar S, Taylor G, Wilson P, Hurst W. Prognostic importance of specific immunoreactivity in occupational bladder cancer. Br.Med f 1980;280:512-3.

19 Cordiali-Fei P, Natali PG, Peci G, Pellegrino MA. Ferrone S. Levels of Ia-like antigen bearing lymphocytes in patients with solid primary tumours. I Clin Lab Immunol 1981:6:197-9.

20 Ginns LC, Ryu JH, Rogol PR, et al. Natural killer cell activity in cigarette smokers and asbestos workers. Am Rev Respir Dis 1985;131:831-4

21 Shamsuddin AKM, Sinopoli NT, Hemminki K, Boesch R, Harris CC. Detection of benzo a pyrene:DNA adducts in human white blood cells. Cancer Res 1985;45:66-8.

22 William CJ. Handling cytotoxics. Br Med J 1985;291:1299-300.

23 Health and Safety Commission. Control of substances hazardous to health. Draft regulations and draft approved codes of practice. London: HMSO, 1984. (Consultative document.

24 Bondi $\mathrm{H}$. Risk in perspective. In: Cooper MG, ed. Risk: man-made hazards to man. Oxford: Clarendon Press, 1985:8-17.

\section{IVF update}

Twenty five centres in Britain are carrying out in vitro fertilisation (IVF). Of these only one is operated by the NHS; so this form of treatment-the only hope for many of Britain's estimated 1 in 10 infertile couples-is readily available only to those who can afford to pay between $£ 1000$ and $£ 2500$ per treatment cycle. Such fees are not surprising, for the cost in salaries and running expenses alone for a unit treating five patients a week is about $£ 100000$. Private clinics must also cover the cost of their beds, new buildings, etc. Irrespective of the high cost the demand is there, and the private centres are flourishing. Indeed, five new centres are on the starting blocks. Waiting lists are long, many as long as four years. This is bad news for those in their late 30 s for if a clinic has a policy of accepting only women under 40 , and many do, today's 35 year old applicants are likely to be turned down. 
The success rate of IVF remains disappointingly low: only about 1000 babies have been born in Britain so far, and of those over 500 started life at the Bourn Hall centre, in Cambridge. Many of the centres have not yet succeeded in getting a pregnancy to term.

In the wake of the Warnock report, which, among other things, recommended that a statutory body should be set up to oversee IVF centres, and public fears that unsupervised scientists might conduct unethical research on spare embryos, the Voluntary Licensing Authority for Human In Vitro Fertilisation and Embryology was set up in March 1985 to fill the void. Its brief was to monitor the activities of the IVF centres until a statutory body was established-something that still appears to be at least a year or 18 months off.

The authority, set up and financed by the Medical Research Council and the Royal College of Obstetricians and Gynaecologists, published its first report last week. ${ }^{1}$ On the face of it the findings are reassuring: all 25 of the IVF centres were quick to invite the authority to inspect them, and 24 were subsequently approved. The remaining one is expected to obtain approval shortly. No evidence of unacceptable or unethical practice was found, and proposals for further research work were sound. Of the 10 centres that are undertaking research, most are concentrating on ways to improve the technique of IVF. Only one centre is looking at genetic abnormalities in the pre-embryo (the approved term for the product of the fertilised egg up to day 15 or 16). Another is concerned with research on a new contraceptive pill and a third with studies of male infertility.

The chances of achieving pregnancy, which is not, of course, synonymous with going to term and producing a normal baby, depend on the selection of patients and the technical skill of the unit, but results from 200 IVF centres world wide with a cumulative experience of 11000 pregnancies yield some hard information. If one pre-embryo is replaced the chances of a pregnancy are about 9.5\%; replacing two increases this to $15 \%$, three to $19 \%$, and four or more to $25 \%$. Replacing more than four embryos puts the mother at high risk of multiple pregnancy and there is also an increased risk of miscarriage, so at present it is widely recommended that three to four embryos should be replaced. This gives the best chance of success, and the multiple pregnancy rate, $14-24 \%$, is acceptable.

Precise rates of pregnancy, pregnancies going to term, selection criteria, and so on for each centre are not known, and the voluntary licensing body, members of which were speaking at a recent press conference at the Royal College of Obstetricians and Gynaecologists, said that they were not about to publish a league table ranking the centres in order of success. They did suggest, however, that prospective patients should ask the centre they approach to give them an idea of its success rate so that they did not embark on treatment with a false sense of optimism.

The licensing authority has not yet delved into the delicate business of recommending who should be offered IVF. Should it be only childless couples? What about those with only one child desperate for a second, or a pair of lesbians, or a commited "one parent" mother? It has, however, tackled the more tangible issues: its recommendations include the suggestion that every centre should have a written policy for the disposal of spare embryos (many centres had no disposal policy at all). Couples must give consent whether their spare embryos should be destroyed, stored, or used for research. It also recommends that the centres should use a standard consent form.

Despite its self confessed lack of statutory power, the voluntary licensing body seems convinced that it has succeeded in its policing role and that no unethical experiments are being carried about behind closed doors. "Our visits are not whitewash expeditions," said the authority's chairman, Dame Mary Donaldson. She did, however, admit that it would be "nice to be made official," although she had no suggestions on how the government could be persuaded to introduce legislation in the near future.

As the demand for IVF continues to grow-and the private sector responds with enthusiasm-is it likely that the National Health Service will be spurred into action to provide a service that is so obviously wanted? Sadly the answer is almost certainly no. No one dies of infertilityexcept by suicide.

\section{TESSA RICHARDS}

Assistant editor,

British Medical fournal

London WC1H 9JR

1 Voluntary Licensing Authority for Human In Vitro Fertilisation and Embryology. First report. London: Medical Research Council/Royal College of Obstetricians and Gynaecologists, 1986.

\section{Pseudo-obstruction}

Murphy and others spoke about "spastic ileus" towards the end of the last century and in the first 40 odd years of the present one. ${ }^{1-4}$ Not, however, until 1948 did Ogilvie identify a cause of this functional obstruction, when he described it in patients with malignant retroperitoneal infiltration. ${ }^{4}$ Shortly thereafter, in company with his Edinburgh surgical colleagues, one of us drew attention to a group of patients who may present in medical, surgical, or orthopaedic wards with appearances which resemble acute mechanical obstruction, usually but not always of the large bowel, but in whom a mechanical cause is not found. ${ }^{5}$ We introduced the term "pseudo-obstruction" for the clinical entity which embraces Ogilvie's syndrome, other causes of retroperitoneal effusion (such as that which occurs after a lumbar spine fracture, ${ }^{6}$ and the intestinal dysfunction in hypoxia, ${ }^{5} 78$ electrolyte imbalance, ${ }^{69-11}$ and uraemia. ${ }^{7} 11$

The term pseudo-obstruction is a misnomer, because the patients are acutely obstructed but they do not need an operation and may do badly after laparotomy for at least two reasons. Firstly, they are often ill from the underlying cause and, secondly, with the abdomen opened the surgeon may make the wrong move and so precipitate disaster.

With the syndrome well delineated it should, perhaps, now be easily recognised and wrong moves should be rare. Unfortunately this is not so. This year we have in our unit taken over the management of two patients operated on elsewhere: both had classical pseudo-obstruction; neither should in retrospect have been treated as if they had mechanical obstruction; one died and the other had a long and difficult convalescence. Sadly the message has yet to strike home.

The context is helpful in making the diagnosis. The patient - often elderly - may be in hospital or in bed at home with some other illness or after an injury such as a fractured hip or pelvis. ${ }^{6}{ }^{12}$ Not infrequently he or she has become dehydrated and mildly uraemic, ${ }^{11}$ a process favoured by renal or cardiac disease, for which the patient may already be 